\title{
Alphonse de Lamartine, Raphaël
}

\section{Valentina Ponzetto}

\section{OpenEdition}

\section{Journals}

Édition électronique

URL : https://journals.openedition.org/studifrancesi/4729

DOI : 10.4000/studifrancesi.4729

ISSN : 2421-5856

\section{Éditeur}

Rosenberg \& Sellier

\section{Édition imprimée}

Date de publication : 1 avril 2012

Pagination : 163-164

ISSN : 0039-2944

\section{Référence électronique}

Valentina Ponzetto, « Alphonse de Lamartine, Raphaël », Studi Francesi [En ligne], 166 (I | LVI) | 2012,

mis en ligne le 30 novembre 2015, consulté le 18 novembre 2021. URL : http://

journals.openedition.org/studifrancesi/4729; DOI : https://doi.org/10.4000/studifrancesi.4729

Ce document a été généré automatiquement le 18 novembre 2021.

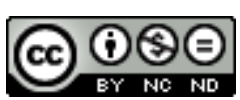

Studi Francesi è distribuita con Licenza Creative Commons Attribuzione - Non commerciale - Non opere derivate 4.0 Internazionale. 


\title{
Alphonse de Lamartine, Raphaël
}

\author{
Valentina Ponzetto
}

\section{RÉFÉRENCE}

ALPHONSE DE LAMARTine, Raphaël, éd. Aurélie loiseleur, Paris, Gallimard, «Folio classique», 2011, pp. 336.

1 Raphaël, sous-titré significativement "pages de la vingtième année», est un roman ouvertement autobiographique et en même temps largement fictionnalisé, «à moitié vrai, à moitié faux", comme l'admettait Lamartine lui-même avec une pointe de regret dans l'un de ses Cours familiers de littérature. En 1848, le poète, homme déjà mûr et engagé en politique, y reprend l'événement fondateur de sa vie artistique et amoureuse: sa rencontre aux eaux d'Aix-les-bains, en septembre 1816, avec Julie Charles, l'Elvire des Méditations, et la brève idylle de leurs amours, désormais devenues légendaires. Si Julie garde ici son prénom, le poète se cache derrière l'identité factice de Raphaël, un double imaginaire qui renoncera à la carrière poétique et terminera ses jours pauvre et inconnu au fond de sa province natale.

2 Dans cette belle édition, Aurélie Loiseleur s'attache à démêler les enjeux de ce texte double, «oscillant entre réalité et fiction, entre roman et poésie» (p.21). Sans indulgence comme sans parti pris, elle reconstruit le travail de transposition des faits réels à la fiction, entre reprises fidèles et changements subtils, qu'illustre aussi de manière synthétique un double tableau chronologique extrêmement clair et utile, publié en fin de volume («Dossier»). Outre le destin du protagoniste / narrateur, le changement principal concerne sa relation avec la femme aimée, relation qui dans le roman devient éthérée, platonique, purement spirituelle. De violents débats ont autrefois divisé les lamartiniens au sujet de cette fable de la chasteté, qui fit beaucoup sourire, mais que certains s'obstinaient à considérer comme une vérité autobiographique jusqu'à la publication par René Doumic, en1905, des quatre seules lettres de Julie Charles à Lamartine ayant échappé à la destruction et reproduites en annexe parmi d'autres documents. 
3 Au-delà de ces querelles d'un autre temps, qu'elle évoque brièvement, A. Loiseleur s'interroge plutôt sur la signification des mensonges romanesques choisis par Lamartine. Ainsi, la relation platonique entre les amants répond au besoin d'autocensure d'un Lamartine écrivant sous l'œil de sa famille et soucieux de préserver la réputation de son ancienne maîtresse, mais aussi au désir d'idéaliser Julie, la rendant l'objet d'un amour proche du culte, sorte d'«amour de loin» aux résonances moyenâgeuses. D'autre part, faire de Raphaël un poète en puissance, dont la fibre poétique est réveillée par l'amour mais qui ne publiera jamais d'ouvrage, est une manière de «récuser à travers son prête-nom l'image stéréotypée du poète maitre de son discours» (p. 20) pour adopter une langue nouvelle, plus brûlante et plus vraie, débarrassée du carcan de la rhétorique. Avec la sensibilité et la plume du poète qu'elle est, A. Loiseleur met en avant la nature éminemment poétique de ce court roman, véritable épure qui «se pense» et «s'écrit comme un poème» (p. 21), et, dans la droite ligne des Méditations, esquisse un retour aux sources de la poésie lamartinienne.

4 Les riches «Annexes» présentent les documents réels qui nourrissent l'intrigue romanesque: la correspondance qui se rapporte à la liaison entre Lamartine et Julie Charles, trois poèmes de Lamartine directement ou indirectement évoqués dans le roman («Invocation», «Ode à M. de Bonald», «Le Lac»), une ballade populaire chantée par Julie et un extrait d'un Cours familier de littérature où le poète évoque encore une fois cet amour de jeunesse pour vanter la supériorité «de l'amour spiritualiste sur l'amour sensuel». 